\title{
FALLOPIA JAPONICA (HOUTT.) RONSE DECR. (POLYGONACEAE): A NEW RECORD FOR THE ALIEN FLORA OF CHILE
}

\author{
FALLOPIA JAPONICA (HOUTT.) RONSE DECR. (POLYGONACEAE), UN \\ NUEVO REGISTRO PARA LA FLORA ADVENTICIA DE CHILE
}

\author{
Alfredo Saldaña ${ }^{1}$, Nicol Fuentes ${ }^{1,2} \&$ Simon Pfanzelt ${ }^{1}$ \\ ${ }^{1}$ Departamento de Botánica, Universidad de Concepción, Casilla 160-C, Concepción, Chile; ${ }^{2}$ Institute of Geobotany \\ and Botanical Garden, Martin Luther University Halle-Wittenberg, Am Kirchtor 1, D-06108 Halle, Germany. \\ asaldana@udec.cl
}

\section{RESUMEN}

La especie introducida Fallopia japonica (Houtt.) Ronse Decr. es registrada por primera vez en Chile fuera de zonas urbanas. Se entrega descripción y fotografía de esta especie, potencial invasora de áreas silvestres protegidas. Los especimenes fueron colectados en la localidad de Correntoso, borde del Parque Nacional Alerce Andino (41 $27^{\prime} 11^{\prime \prime}$; 72॰39'32”W).

The Polygonaceae family includes 62 species in Chile (Marticorena 1990). The number of alien plant species are 20 including this new record. Originally an East Asian native, Fallopia japonica (Houtt.) Ronse Decr. has been introduced as a garden ornamental plant to northern and central Europe, North America, Australia, and New Zealand (ISSG 2009). The species of the genus Fallopia possess many of the features of an "ideal invader" and are considered among the most vigorous European aliens (Beerling et al. 1995). A previous study has shown that once Fallopia taxa invade a site, their persistence is very high (Pyšek et al. 2001). Fallopia japonica is cultivated as an ornamental plant throughout southern Chile, but to our knowledge, it is not reported as an invasive plant in natural environments.

\section{TAXONOMY}

Fallopia japonica (Houtt.) Ronse Decr. L. Ronse Decraene, Bot. J. Linn. Soc. 98(4): 369. 1988. Basionym: Reynoutria japonica Houtt. Nat. Hist. 2(8): 640, pl. 51, f. 1. 1777.

Synonyms: Pleuropterus cuspidatus (Siebold \& Zucc.) Gross, Polygonum confertum Hook.f., P. cuspidatum Siebold \& Zucc., P. reynoutria Makino, Reynoutria hastata Nakai, Tiniaria japonica (Houtt.) Hedberg. Icon: Institute of Botany of Chinese Academy of Sciences. 1972. Iconographia Cormophytorum Sinicorum Tomus I: 1157, fig. 1134.
Rather stout dioecious, herbaceous perennial with thick rhizomes; stems ascending from an erect base, 50-150 cm long, hollow, branched above; leaves broadly ovate, $6-15 \mathrm{~cm}$ long, acuminate, papillose to scabrous beneath, usually truncate at base, the petioles 1-3 cm long, sheaths thinly membranous (Figs. 1a, 1c); spike branched, numerous, terminal, paniculate, flowers densely arranged (Fig. 1b), white, $2.5-3 \mathrm{~mm}$ long, the pistillate accrescent after anthesis; fruit with the outer perianth segments winged on back, 6-10 mm long, subcuneate at base; achenes ovate-elliptic, 2-2.5 mm long, black-brown, lustrous, acutely trigonous (Jisaburo 1965).

Fallopia contains 12 climbing and erect, annual and perennial, herbaceous and woody species, native to China, Taiwan, Korea, southeastern Siberia, and Japan (Jisaburo 1965, Kim \& Park 2000). The taxonomy of Fallopia has long been debated. Some authors separate the annual and perennial climbers from the erect, herbaceous perennials, giving generic rank to the latter under Reynoutria (e.g. Haraldson 1978). In the present paper, we adopt the taxonomic classification of Ronse Decraene \& Akeroyd (1988), which is supported by the results of cytological examinations (Bailey \& Stace 1992) and sequence data from the chloroplast genes $r b c L$ (Frye \& Kron 2003), trnL-F and matK (Yu et al. 2008), and recognize Fallopia japonica as a member of Fallopia Sect. Reynoutria. 


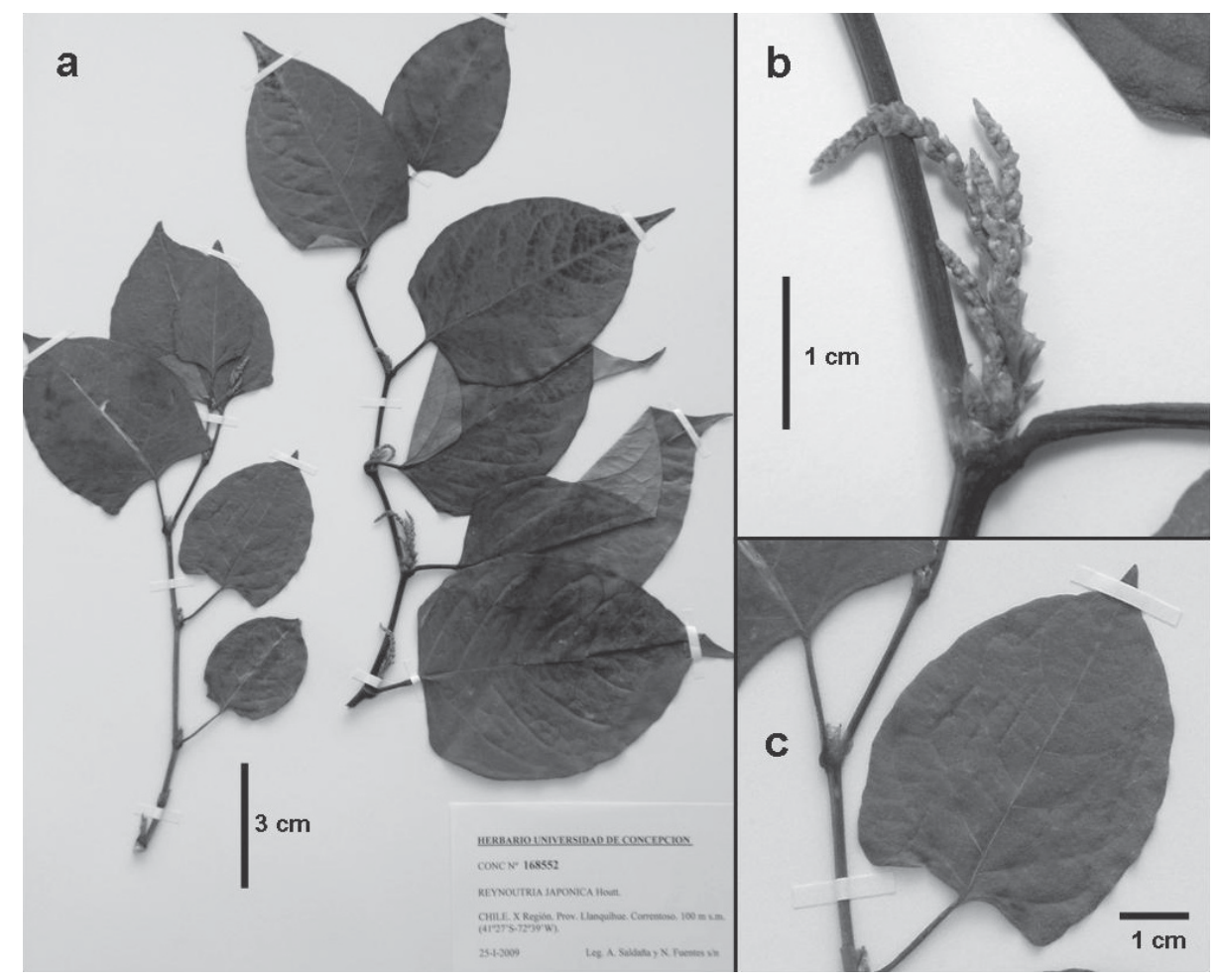

Figura 1. Fallopia japonica (Houtt.) Ronse Decr. a) Tallos con hojas e inflorescencias axilares en antesis. b) Detalle de las inflorescencias axilares. c) Detalle de la hoja (fotografías de N. Fuentes; espécimen CONC No 168552).

Figure 1. Fallopia japonica (Houtt.) Ronse Decr. a) Branch with leaves and axillars inflorescences in anthesis. b) Detail of the axillar inflorescences. c) Detail of the leaf (photographs by N. Fuentes; specimen CONC No 168552 ).

\section{ECOLOGICAL CHARACTERISTICS}

Invaded habitats are woodland, forest edge, riparian environments, wetlands, floodplains, and disturbed sites. Plants spread easily by vegetative fragments in water and thus represent a major threat to the adjacent riparian vegetation (Brabec \& Pyšek 2000). Forming monoespecific stands, an extensive $F$. japonica population may reduce river flow and promote soil erosion (Weber 2003). The high regeneration potential of $F$. japonica has been documented not only for rhizomes but also stem fragments (Brock et al. 1995, Seiger \& Merchant 1997) and establishment from fallen leaves has even been observed (Brabec \& Pyšek 2000). Affinity to human settlements reflects their crucial role as dispersal foci for F. japonica that is planted in cities, towns and villages from where it is spread into open landscape by people, water courses or soil movement during building activities. The stout rhizome forms a deep mat and can grow more than two meter in depth and 15-20 $\mathrm{m}$ in length (Child \& Wade 2000, Weber
2003). Control is difficult due to vigorous rhizome growth. Frequent cutting, e.g. at least every four weeks, reduces belowground biomass allocation but cutting alone does not eliminate the plant (Seiger \& Merchant 1997, Weber 2003). Besides, there is growing evidence of sexual reproduction events by hybridization between $F$. japonica and congeneric species in their adventive range in Europe (Pyšek et al. 2003, Mandák et al. 2005, Tiébré et al. 2007), which may result in rendering Fallopia species even more aggressive invaders.

Given the reported invasive potential of $F$. japonica, its ability to function as an ecosystem engineer (Kappes et al. 2007), and the fact that we found a population of this species established at the border of Alerce Andino National Park, further surveys will be neccesary to determine whether this species will spread as other alien shrub species that became invasive in southern Chile (e.g. Ulex europaeus L., Cytisus scoparius (L.) Link). 


\section{Material STUdied}

CHILE. Región de los Lagos, Prov. Llanquihue,

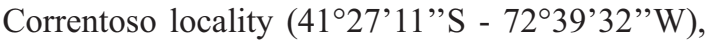
January 25, 2009, $158 \mathrm{~m}$ a.s.1. altitude. A. Saldaña (CONC 168552).

\section{ACKNOWLEDGMENTS}

The authors wish to thankA. Marticorena, R. Rodríguez (CONC) for their assistance in species determination, and an anonymous reviewer for valuable remarks on an earlier version of the manuscript. S. Pfanzelt gratefully acknowledges funding support of the Dr. Karl Wamsler Foundation.

\section{BIBLIOGRAPHY}

Bailey, J.P. \& C.A. Stace. 1992. Chromosome number, morphology, pairing, and DNA values of species and hybrids in the genus Fallopia (Polygonaceae). Plant Systematics and Evolution 180(1-2): 29-52.

Beerling, D.J., J.P. Bailey \& A.P. Conolly. 1994. Biological flora of the British Islands. Fallopia japonica (Houtt.) Ronse Decraene (Reynoutria japonica Houtt.; Polygonum cuspidatum Sieb. \& Zucc.). Journal of Ecology 82(4): 959-979.

Beerling, D.J., B. Huntley \& J.P. Bailey. 1995. Climate and the distribution of Fallopia japonica: use of an introduced species to test the predictive capacity of response surface. Journal of Vegetation Science 6(2): 269-282.

Brabec, J. \& P. PYšEK. 2000. Establishment and survival of three invasive taxa of the genus Reynoutria (Polygonaceae) in mesic mown meadows: a field experimental study. Folia Geobotanica 35(1): 27-42.

Brock, J.H., L.E. Child, L.C. De WaAl \& P.M. WADE. 1995. The invasive nature of Fallopia japonica is enhanced by vegetative regeneration from stem tissues. In: P. Pyšek, K. Prach, M. Rejmanek \& M. Wade (eds.), Plant invasions: general aspects and special problems, 131-139. SPB Academic Publishing, Amsterdam.

Child, L.E. \& P.M. WADE. 2000. The Japanese knotweed manual: the management and control of an invasive alien weed. Chichester, Packard Publishing Ltd. Chichester UK.

Frye, A.S.L. \& K.A. Kron. 2003. $r b c L$ phlyogeny and character evolution in Polygonaceae. Systematic Botany 28(2): 326-332.

Global Invasive Species Database (ISSG). 2009. URL: http://www.issg.org. Viewed: March 5, 2009.

HaRALDSON, K. 1978. Anatomy and taxonomy in Polygonaceae subfam. Polygonoidae Meisn. emend. Jaretzky. Symbolae Botanicae Upsaliensis 22(2): 1-95.

JisABURO, O. 1965. Flora of Japan (in English). Edited by F.G. Meyer \& E.H. Walker. Smithsonian Institution, Washington, D.C. 1067 pp.

Kappes, H., R. Lay \& W. Topp. 2007. Changes in different trophic levels of litter-dwelling Macrofauna associated with giant knotweed. Ecosystems 10(5): 734-744.

KIM, J.Y. \& C. PARK. 2000. Morphological and chromosomal variation in Fallopia section Reynoutria (Polygonaceae) in Korea. Brittonia 52(1): 34-48.

MandÁk, B., K. BímovÁ, P. PYŠEK, J. ŠTĚPÁNeK \& I. PlaČKovÁ. 2005. Isoenzyme diversity in Reynoutria (Polygonaceae) taxa: escape from sterility by hybridization. Plant Systematics and Evolution 253(1-4): 219-230.

Marticorena, C. 1990. Contribución a la estadística de la flora vascular de Chile. Gayana Botánica 47 (3-4): 85-113.

Pyšek, P., B. Mandák, T. Francírková \& K. Prach. 2001. Persistence of stout clonal herbs as invaders in the landscape: a field test of historical records. In: G. Brundu, J. Brock, I. Camarda, L. Child \& M. Wade (eds.), Plant invasions: Species ecology and ecosystem management, p. 235244. Backhuys Publishing, Leiden.

Ronse DeCRAENE, L.P. \& J.R. AKeroyd. 1988. Generic limits in Polygonum and related genera (Polygonaceae) on the basis of floral characters. Botanical Journal of the Linnean Society 98(4): 321-371.

Seiger, L.A. \& H.C. Merchant. 1997. Mechanical control of Japanese knotweed (Fallopia japonica [Houtt.] Ronse Decraene): Effects of cutting regime on rhizomatous reserves. Natural Areas Journal 17(4): 341-345.

Tiébré, M.S., S. Vanderhoeven, L. SaAd \& M. Grégory. 2007. Hybridization and sexual reproduction in the invasive alien Fallopia (Polygonaceae) complex in Belgium. Annals of Botany 99(1): 193-203.

WeBer, E. 2003. Invasive plant species of the world: a reference guide to environmental weeds. CABI Publishing, Wallingford, UK. 560 pp.

Yu, W., S. Fan, C. Xu, L. Zhu, Y. Hou, F. Lin \& F. Li. 2008. Systematic position of Reynoutria and Polygonum sibiricum inferred from sequences of chloroplast $\operatorname{trn} \mathrm{L}-\mathrm{F}$ and $m a t \mathrm{~K}$. Journal of Systematics and Evolution 46(5): 676-681. 